\title{
Increased Serum Levels of Inflammatory Mediators and Low Frequency of Regulatory T Cells in the Peripheral Blood of Preeclamptic Mexican Women
}

\author{
Mario Adan Moreno-Eutimio, ${ }^{1}$ José María Tovar-Rodríguez, ${ }^{2}$ \\ Karina Vargas-Avila, ${ }^{1}$ Nayeli Goreti Nieto-Velázquez, ${ }^{1}$ María Guadalupe Frías-De-León, \\ Mónica Sierra-Martinez, ${ }^{3}$ and Gustavo Acosta-Altamirano ${ }^{2}$ \\ ${ }^{1}$ Immunobiology Laboratory, Hospital Juárez de México, Ministry of Health, 07760 Mexico City, Mexico \\ ${ }^{2}$ Research Directorate, Hospital Juárez de México, Ministry of Health, 07760 Mexico City, Mexico \\ ${ }^{3}$ Molecular Genetics Laboratory, Hospital Juárez de México, Ministry of Health, 07760 Mexico City, Mexico
}

Correspondence should be addressed to Mario Adan Moreno-Eutimio; marioadan@inmunoquimica.com

Received 2 July 2014; Accepted 15 September 2014; Published 7 December 2014

Academic Editor: Gail B. Mahady

Copyright ( 2014 Mario Adan Moreno-Eutimio et al. This is an open access article distributed under the Creative Commons Attribution License, which permits unrestricted use, distribution, and reproduction in any medium, provided the original work is properly cited.

\begin{abstract}
Regulatory $\mathrm{T}$ cells $\left(\mathrm{T}_{\text {regs }} ; \mathrm{CD} 4+\mathrm{CD} 25^{\text {high }}\right.$ Foxp3+) are critical in maintaining immune tolerance during pregnancy and uterine vascularization. In this study, we show that, in Mexican women with different preeclamptic severity levels, the number of $T_{\text {regs }}$ and the subset of CD4+CD $25^{\text {high }}$ Foxp3+ are decreased compared with those of normotensive pregnant women (NP). Moreover, a systemic inflammatory state is a pivotal feature in the pathogenesis of this disorder and could be related to hypertension and endothelial dysfunction. Likewise, we observed elevated levels of IL-6, TNF- $\alpha$, and IL- 8 in the serum of severe preeclamptic patients (SPE); no differences were found in the IL- $\beta$ and IL-10 levels compared with those of NP patients. An analysis of chemokines in the preeclamptic serum samples showed high levels of CXCL10, CCL2, and CXCL9. Our findings suggest that the preeclamptic state is linked with systemic inflammation and reduced numbers of $\mathrm{T}_{\text {regs }}$.
\end{abstract}

\section{Introduction}

Preeclampsia (PE) is a complication of pregnancy that is characterized by hypertension, proteinuria, and maternal systemic inflammation after 20 weeks of gestation, when innate and adaptive responses play roles in the pathogenesis of this disorder [1]. PE is an important cause of maternal and fetal morbidity and mortality worldwide. In developing countries, such as Mexico, 34\% of maternal deaths are linked to $\mathrm{PE}$, which is also the major cause of premature delivery [2]. Several factors, such as first pregnancy, a maternal age $>40$, hypertension, obesity, and single nucleotide polymorphisms in several genes, including those involved in angiotensin activity and oxidative stress, have been associated with PE development [1,3-6].

Although the pathogenesis of PE is not fully understood, several works have linked inflammation to cardinal features of this disorder. For instance, preeclamptic placenta secretes several inflammatory molecules as a result of the hypoxic state developed from a lack of vessel remodeling in the uterus [7-9].

It is well known that regulatory $\mathrm{T}$ cells $\left(\mathrm{T}_{\text {regs }}\right)$ are a particular subset of $\mathrm{T}$ lymphocytes (CD4+, CD25 $5^{\text {high }}$, Foxp3+) that maintain immunological self-tolerance, suppress the inflammatory state, and induce immune homoeostasis [10, 11]. During pregnancy, $\mathrm{T}_{\text {regs }}$ are able to maintain immune tolerance by suppressing natural killer (NK) cells and $\mathrm{T}$ cell responses against allogeneic paternal antigens and selfantigens involved in rejection and labor complications such as PE $[8,12]$. Additionally, a number of findings have indicated that the increased expression of inflammatory mediators, such as cytokines and chemokines, could be potential mediators of endothelial dysfunction in preeclamptic patients [13]. 
TABLE 1: Clinical characteristics of patients with preeclampsia, normotensive pregnant, and nonpregnant healthy women.

\begin{tabular}{|c|c|c|c|c|}
\hline & $\begin{array}{l}\text { Nonpregnant } \\
\text { healthy women } \\
(n=27)\end{array}$ & $\begin{array}{c}\text { Moderated } \\
\text { preeclamptic } \\
(n=49)\end{array}$ & $\begin{array}{c}\text { Severe } \\
\text { preeclamptic } \\
(n=24)\end{array}$ & $\begin{array}{c}\text { Normotensive } \\
\text { pregnant } \\
(n=51)\end{array}$ \\
\hline $\begin{array}{l}\text { Age (years) } \\
(\text { means } \pm S D)\end{array}$ & $22.7 \pm 2.53$ & $24.9 \pm 7.21$ & $23.78 \pm 5.68$ & $26.04 \pm 7.37$ \\
\hline \multicolumn{5}{|l|}{ Parity } \\
\hline Primiparous & $2(7.4 \%)$ & $26(53 \%)$ & $13(59 \%)$ & $21(41 \%)$ \\
\hline Multiparous & $1(3.7 \%)$ & $23(47 \%)$ & $11(41 \%)$ & $30(59 \%)$ \\
\hline \multicolumn{5}{|l|}{ Blood pressure (mmHg) } \\
\hline Systolic & $110.25 \pm 15.15$ & $158.2 \pm 16.75^{*}$ & $175.3 \pm 11.28^{*}$ & $110.3 \pm 18.15$ \\
\hline Diastolic & $73.64 \pm 7.11$ & $101.4 \pm 5.31^{*}$ & $119.3 \pm 6.22^{*}$ & $71.5 \pm 6.32$ \\
\hline $\begin{array}{l}\text { Gestational age at sampling } \\
\text { (weeks) }\end{array}$ & NA & $\begin{array}{c}38.5 \\
(30-41)\end{array}$ & $\begin{array}{c}35.8 \\
(30-40)\end{array}$ & $\begin{array}{c}38.4 \\
(30-41)\end{array}$ \\
\hline $\begin{array}{l}\text { Gestational age at delivery } \\
\text { (weeks) (median, range) }\end{array}$ & NA & $\begin{array}{c}38.5 \\
(30-41)\end{array}$ & $\begin{array}{c}35.8^{*} \\
(30-40)\end{array}$ & $\begin{array}{c}39.4 \\
(35-41)\end{array}$ \\
\hline $\begin{array}{l}\text { Infant weight (grams) (mean, } \\
\text { range) }\end{array}$ & NA & $\begin{array}{c}2610.8 \\
(560-3570) \\
\end{array}$ & $\begin{array}{c}1617.9^{*} \\
(460-3110)\end{array}$ & $\begin{array}{c}2888.49 \\
(780-3850)\end{array}$ \\
\hline
\end{tabular}

${ }^{*} P<0.05$ preeclamptic patients versus normotensive pregnant women.

NA, not applicable.

A normal pregnancy is characterized by a shift toward Th2type immunity and the inhibition of cytotoxic Th1 immune responses [8].

Several soluble factors, such as chemokines and cytokines, play key roles during inflammation in PE. For instance, chemokines, which are chemotactic cytokines, participate in several biological processes, such as cellular lymphoid organogenesis, angiogenesis, and adhesion molecules expression [14]. In addition to the secretion of inflammatory cytokines such as IL- 6 and TNF- $\alpha$, the amount of circulating chemokines is elevated in PE [15-17].

Several studies have been published describing that normal human pregnancy is associated with elevated numbers of $\mathrm{T}_{\text {regs }}$ cells [18]. Whether deficiencies in the number or function of $\mathrm{T}_{\text {regs }}$ cells are implicated in the development of preeclampsia remains controversial. Recent reports described decreased numbers of $\mathrm{T}_{\text {regs }}$ cells in preeclampsia compared with normal pregnancy [19-24], whereas others found comparable frequencies $[25,26]$. Furthermore, most of these studies used CD25 as a $\mathrm{T}_{\text {regs }}$ cell marker. However surface markers such as CD25 are also dynamically expressed on the surface of newly activated CD4+ T-helper cells. Using the intracellular marker Foxp3 is therefore superior and more accurate. Moreover, numerous studies have indicated that ethnicity may be associated with the risk of preeclampsia [27]. A recent study has shown that Mexican women have the highest risk to develop preeclampsia [28].

The purpose of the present study was to evaluate the number of $\mathrm{T}_{\text {regs }}$ in Mexican women with $\mathrm{PE}$ and evaluate their correlation with the circulating chemokines and cytokines.

\section{Material and Methods}

2.1. Patients and Healthy Donors. Forty-nine moderated preeclamptic pregnant (MPE), 24 severe preeclamptic pregnant
(SPE), 51 normotensive pregnant (NP), and 27 nonpregnant healthy control (HC) women were studied. The study participants were enrolled in the Department of Obstetrics and Gynecology of the Hospital Juárez de México. Ethical approval for the study was obtained from the Hospital Juárez de México Ethics Committee. All women were informed of the goal of the study, and informed consent was obtained from all patients. The MPE group comprised women matching the diagnostic criteria of the International Society for the Study of Hypertension in Pregnancy (ISSHP) [29]: two blood pressure readings of $\geq 140 / 90 \mathrm{mmHg}$ were taken at least with $>300 \mathrm{mg}$ proteinuria over 24 hours or +1 on dipstick analysis. The SPE group comprised women matching the diagnostic criteria of the ISSHP: two blood pressure readings of $\geq 160 / 110 \mathrm{mmHg}$ were taken at least with $>5 \mathrm{~g}$ proteinuria over 24 hours or +3 on dipstick analysis. None of the patients had HELLP syndrome or eclampsia. The exclusion criteria for this group included concurrent medical problems that may result in disordered inflammatory responses, such as diabetes, autoimmune diseases, and the spontaneous rupture of membranes. Fifty-one maternal blood samples were drawn from normotensive pregnant women who all delivered healthy babies. These were matched by gestational age to the moderated preeclamptic pregnant group at the time of blood sampling. All pregnancies were singleton.

Clinical characteristics of patients with preeclampsia, normotensive pregnant women, and nonpregnant healthy women are summarized in Table 1.

2.2. Blood Sample Collection. Four $\mathrm{mL}$ of whole blood were collected from the antecubital vein of each subject. These samples were centrifuged (Heraeus Megafuge 40R, Thermo Fisher Scientific Inc., MA, USA) at $2500 \mathrm{rpm}$ for $15 \mathrm{~min}$ to 
isolate the supernatant, which was frozen at $-70^{\circ} \mathrm{C}$ until analysis of the cytokine and chemokine profiles.

2.3. Isolation of Peripheral Blood Mononuclear Cells. Peripheral blood samples from all women were collected into EDTA tubes (Becton Dickinson and Company, Franklin Lakes, NJ, USA). All of the blood samples were processed within $2 \mathrm{~h}$ after sampling. Peripheral blood mononuclear cells (PBMC) were isolated using the density centrifugation technique (Ficoll-Paque PLUS, Amersham Biosciences, Uppsala, SE) and then immediately utilized.

2.4. Flow Cytometric Analysis of $T_{\text {regs. }}$. To identify $\mathrm{T}_{\text {regs, }}$, PBMC were stained both for surface antigens with a FITCconjugated $\mathrm{mAb}$ specific for $\mathrm{CD} 4$ and a PE-conjugated $\mathrm{mAb}$ specific for CD25 and for intracellular molecules with an APC-conjugated mAb specific for Foxp3 (eBioscience, San Diego, CA, USA) in accordance with the manufacturer's instructions. Briefly, $1 \times 10^{6}$ PBMC were stained with fluorochrome-conjugated $\mathrm{mAbs}$ specific for cell surface antigen markers for $20 \mathrm{~min}$ in the dark at $4^{\circ} \mathrm{C}$. After the initial staining, the cells were washed twice using phosphate buffered saline (PBS) at $\mathrm{pH} 7.4$, followed by surface marker fixation. To stain for intracellular Foxp3, cells were first permeabilized with a permeabilization/fixation buffer (eBioscience, San Diego, CA, USA) and then stained using the antiFoxp $3 \mathrm{mAb}$. The negative control samples were incubated with isotype-matched antibodies. After incubation, the cells were resuspended in $200 \mu \mathrm{L}$ of PBS for subsequent flow cytometry analysis using an Accuri C6 flow cytometer (BD Biosciences, San Jose, CA, USA). The resultant data were analyzed using the FlowJo software V10 (Tree Star, San Carlos, CA, USA).

Lymphocytes were gated based on both forward and side scatter parameters, FSC and SSC, respectively. After additional gating for CD4+ cells, the proportions of CD4+CD25+, CD4+Foxp3+, and CD $4+C D 25^{\text {high }}$ Foxp3+ cells were determined.

2.5. Cytokines and Chemokines. Serum samples obtained from patients were analyzed for cytokine and chemokine levels using a BD cytometric bead array (CBA) human chemokine kit and a human inflammatory cytokine kit (BD Biosciences, San Jose, CA) according to the manufacturers' instructions. Capture beads were first added to the serum sample, followed by the PE detection reagent. The samples were incubated for $3 \mathrm{~h}$ at room temperature, washed with the assay wash buffer, and suspended again in wash buffer. CBAs were then run on an Accuri C6 flow cytometer and analyzed using the FCAP Array v3.0.1 software (Soft Flow Hungary Ltd, Pécs, Hungary).

2.6. Statistical Analysis. Normality was determined using Shapiro-Wilk test. The significance of the difference between groups was analyzed with one-way ANOVA test with Bonferroni correction. Analyses were performed using GraphPad Prism v5.0 (GraphPad Software Inc., San Diego, CA, USA).

\section{Results}

3.1. Decreased Percentage of $T_{\text {regs }}$ Was Found in Preeclamptic Patients with Different Severity Levels of the Disorder. To evaluate the presence of $\mathrm{T}$ cells in healthy pregnant patients and preeclamptic patients with MPE and SPE, we characterized the percentage of CD4+CD25+ cells that represent the total of CD4+-activated T cells plus $\mathrm{T}_{\text {regs }}$ populations (Figure 1(a)). Our results showed no differences between the groups with $\mathrm{PE}$ and both the HC and NP.

Furthermore, CD4+Foxp3+ cells significantly decreased in women with $\operatorname{MPE}(P<0.05)$ and SPE $(P<0.001)$ in comparison with NP. The NP group also presented an elevated percentage of CD4+Foxp3+ $(P<0.05)$ compared with HC (Figure 1(b)).

In addition to $\mathrm{CD} 4+$ Foxp3+, we evaluated the percentage of CD $4+C D 25^{\text {high }}$ Foxp3 + cells (Figure $1(\mathrm{c})$ ), which express high levels of CD25 and are related to potent suppressor activity mediated by cell contact. Our findings show that MPE $(P<0.01)$ and SPE $(P<0.05)$ patients had lower percentages of both CD $4+\mathrm{CD} 25^{\text {high }}$ Foxp3+ and CD4+Foxp3+ cells. These data, and as was described in several works, indicate that different $\mathrm{T}_{\text {regs }}$ subsets are decreased in preeclamptic patients. The number of CD $4+C D 25^{\text {high }}$ Foxp3+ cells represent $1-2 \%$ of the total CD4+ circulating cells, which is the most potent suppressor subset of $\mathrm{T}_{\text {regs }}$ for the maintenance of immune tolerance and homoeostasis, as related to hypertension during pregnancy.

3.2. Preeclampsia Is Associated with a Higher Circulating Concentration of Inflammatory Cytokines. In patients at different stages of PE, we measured the circulating levels of inflammatory cytokines that have been linked with complications in this disorder. In SPE patients, our results show that the level of inflammatory cytokines, such as IL-6, TNF- $\alpha$, and IL-8, were higher than those in NP $(P<0.01, P<0.01$, and $P<0.001$, resp. $)$ and $\operatorname{MPE}(P<0.01, P<0.05$, and $P<0.001$, resp., Figures 2(b) $-2(d))$.

Interestingly, the concentrations of IL- $1 \beta$ and IL-10 across the different groups of patients were approximately the same (Figures 2(a) and 2(e)).

3.3. Chemokines Related to Antiangiogenic Properties and Inflammatory States Are Increased in Preeclamptic Patients. A number of studies have shown that the correct balance between angiogenic and antiangiogenic mediators is critical for the pathogenesis of PE [30]. We detected higher concentrations of CXCL10 $(P<0.001)$ and CXCL9 $(P<0.001)$ in serum from patients with SPE compared with those in MPE and NP (Figures 3(a) and 3(c)).

CXCL10 and CXCL9 are CXC inflammatory chemokines that also act as positive modulators of pathogenesis. The levels of these chemokines are important in PE due to the inadequate blood vessel remodeling. Additionally, these CXC chemokines are secreted in an IFN- $\gamma$-induced Thl cytokine environment.

The analyzed SPE patients also presented elevated concentrations of CCL2 in serum compared with the NP 


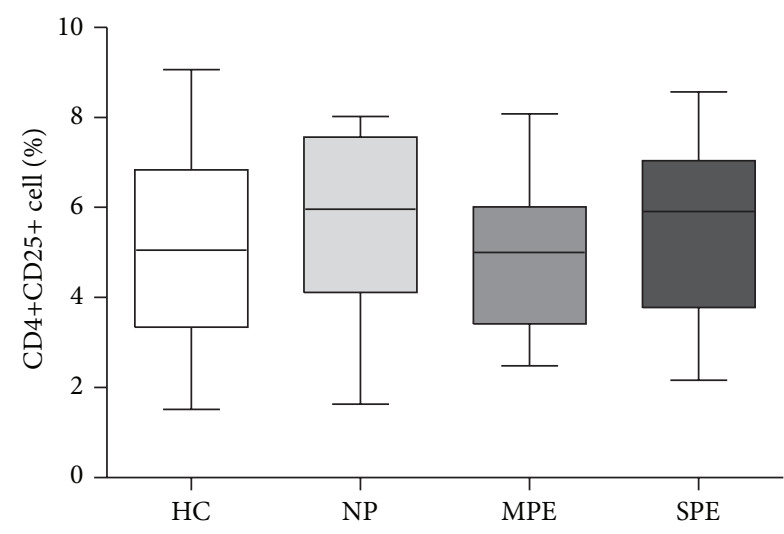

(a)

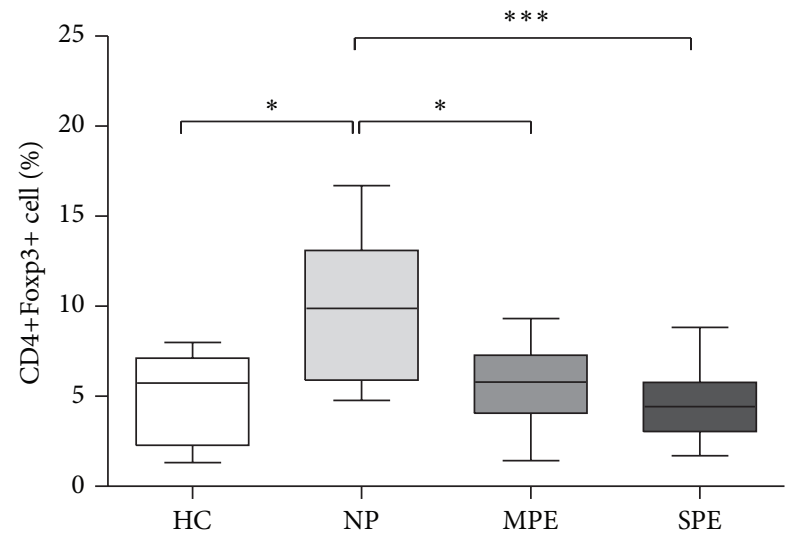

(b)

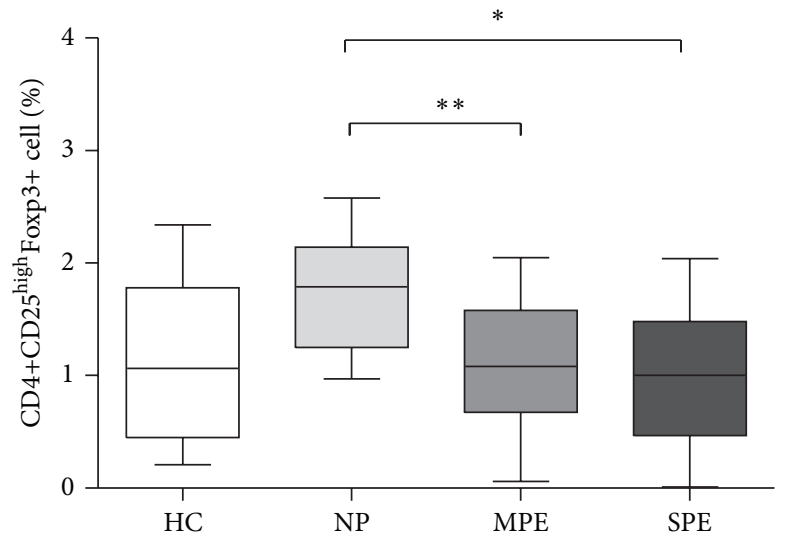

(c)

Figure 1: $\mathrm{T}_{\text {regs }}$ frequency is reduced in preeclamptic patients. Comparison of the frequency of CD4+CD25+ cells (a), CD4+Foxp3+ cells (b), and CD4+CD25 $5^{\text {high }}$ Foxp3+ cells (c) in peripheral maternal blood (levels as percentage of CD4+ cells) in healthy pregnant controls and preeclamptic patients. HC: healthy control; NP: normotensive pregnant; MPE: moderated preeclamptic; SPE: severe preeclamptic $\left({ }^{*} P<0.05\right.$, ${ }^{* *} P<0.01$, and $\left.{ }^{* * *} P<0.001\right)$.

$(P<0.001)$ and $\operatorname{MPE}(P<0.001)$ patients. These data are also a marker of the systemic inflammatory state in PE (Figure 3(b)).

Interestingly, we did not observe differences in the circulating concentrations of CCL5 between the different patient groups (Figure 3(d)), despite evidence of preeclamptic associations with this CCL chemokine in previous studies.

\section{Discussion}

During pregnancy, immune cells, as $\mathrm{T}_{\text {regs }}$ cells, that are present in the decidua have a crucial role in maintaining overall homeostasis but have also been implicated in complications such as PE $[8,13]$. In the present study, we observed reduced levels of conventional $\mathrm{T}_{\text {regs }}\left(\mathrm{CD} 4+\mathrm{CD} 25^{\text {high }}\right.$ Foxp3+ and CD4+Foxp3+) cells in MPE and SPE patients (Figure 1). These data, which correlate with those obtained in previous studies, indicate that $\mathrm{T}_{\text {regs }}$ subsets are decreased in preeclamptic patients and play key roles in maintaining tolerance $[19,20,31]$.
Some studies have suggested that, during pregnancy, $\mathrm{T}$ cell responses are reduced by several mechanisms, including the generation of naturally occurring $\mathrm{T}_{\text {regs }}$, which normally comprise $5-10 \%$ of peripheral CD4+ T cells, or induced $\mathrm{T}_{\text {regs }}$ expressing specific paternal antigens in the mother $[8,13]$. Our data suggest that the changes in the levels between $T_{\text {regs }}$ subsets in Mexican patients may play a role in the pathogenesis of $\mathrm{PE}$, as previously described by other groups, that suggested that alloantigen-induced $\mathrm{T}_{\text {regs }}$ $\left(\mathrm{CD} 4+\mathrm{CD} 25^{\text {high }}\right.$ Foxp3+) may suppress antigens from the fetus.

More recent studies have linked inflammation and a loss of maternal tolerance with PE. Likewise, many experimental works have implicated inflammation with hypertension, which is one of the principal causes of PE complications. Additionally, alterations in the immune response have been implicated in hypertension. For instance, neural $\mathrm{T}$ cell activation is increased in hypertension, and athymic mice present hypertension induced by mineralocorticoids $[9,32$, 33]. Although $\mathrm{T}$ cell response counters the lack of immune tolerance during PE pregnancy complications, the maternal 


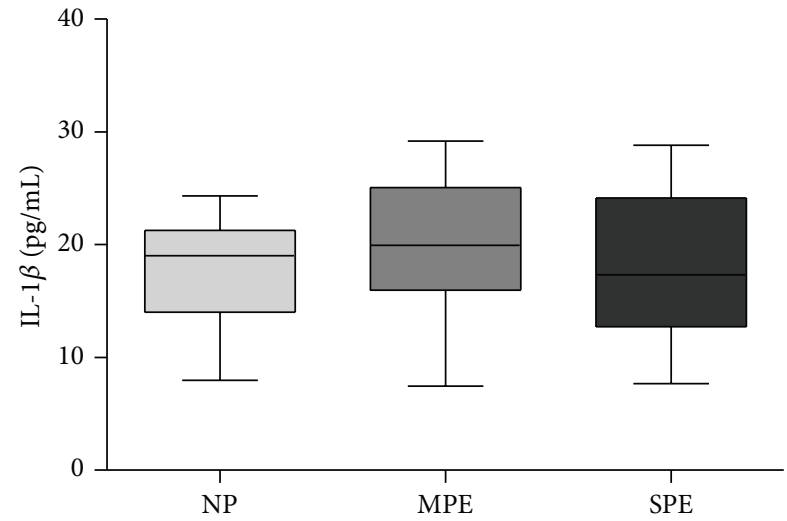

(a)

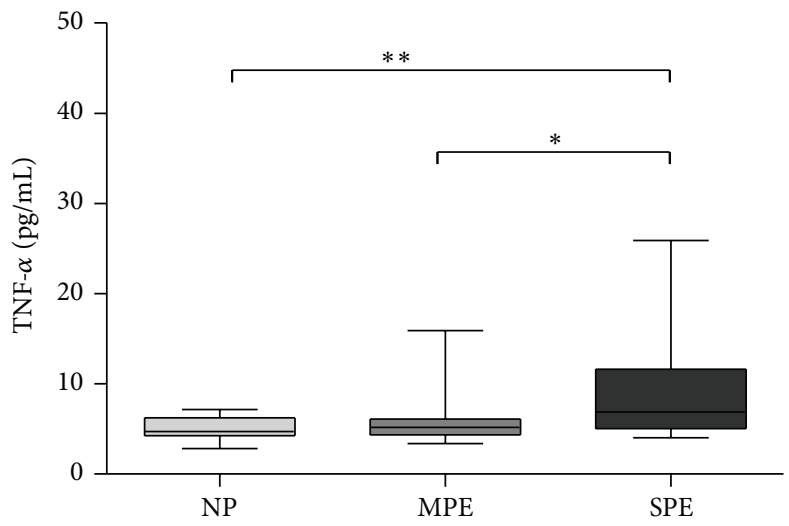

(c)

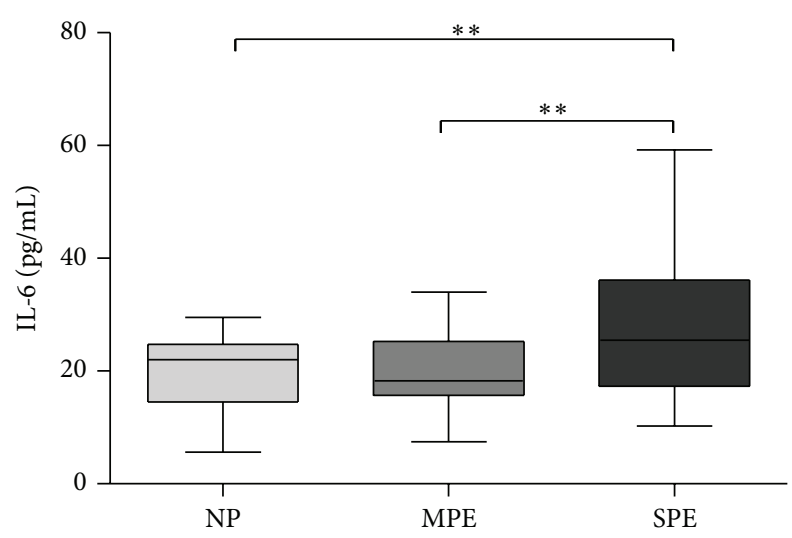

(b)

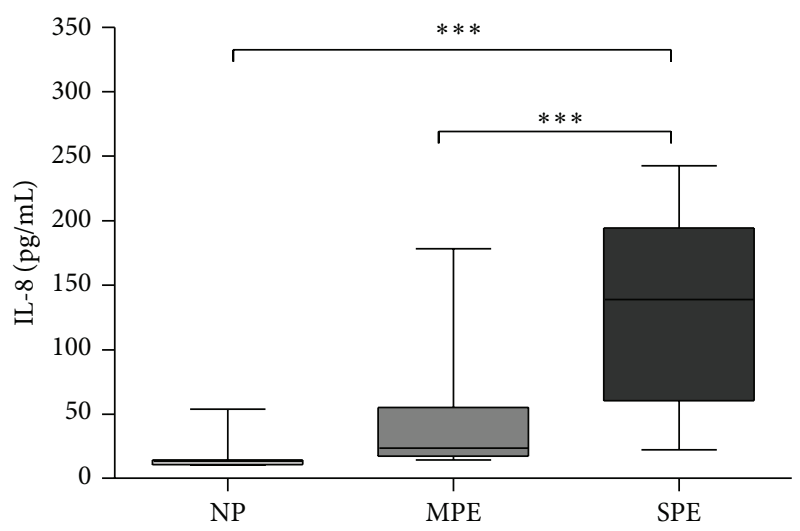

(d)

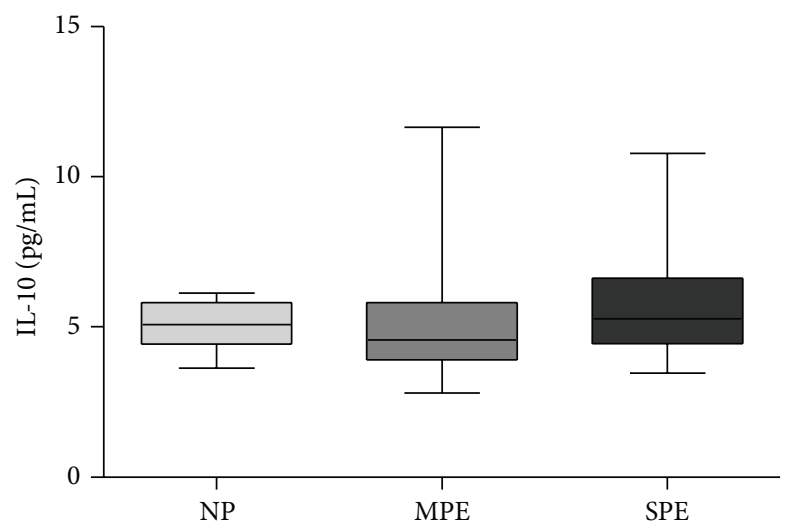

(e)

FIGURE 2: Inflammatory cytokines are deregulated in SPE patients. Plasma levels of inflammatory mediators are elevated in preeclamptic women. Plasma was obtained from normotensive pregnant $(n=51)$, moderated preeclamptic pregnant $(n=49)$, and severe preeclamptic pregnant $(n=24)$ women and inflammatory markers were analyzed by CBA microarrays $\left({ }^{*} P<0.05,{ }^{* *} P<0.01\right.$, and $\left.{ }^{* * *} P<0.001\right)$.

systemic inflammation is activated by the innate immune system, which leads to neutrophil, monocyte, and NK cell activation.

Regarding innate inflammation, our data showed that patients with SPE had elevated circulating concentrations of cytokines compared with MPE and NP patients. In particular, SPE patients had elevated levels of IL-6 in serum, a cytokine that is widely implicated in systemic inflammation and associated with hypertension [34]; in fact, several animal models have shown that IL- 6 is one of the mediators of hypertension under hypoxic conditions in the placenta [33, 35].

The TNF- $\alpha$ concentrations were elevated in serum in SPE patients, but not in NP and MPE patients. This cytokine has been directly correlated to hypertension because the activation of the AT1 receptor induces TNF- $\alpha$ secretion; 


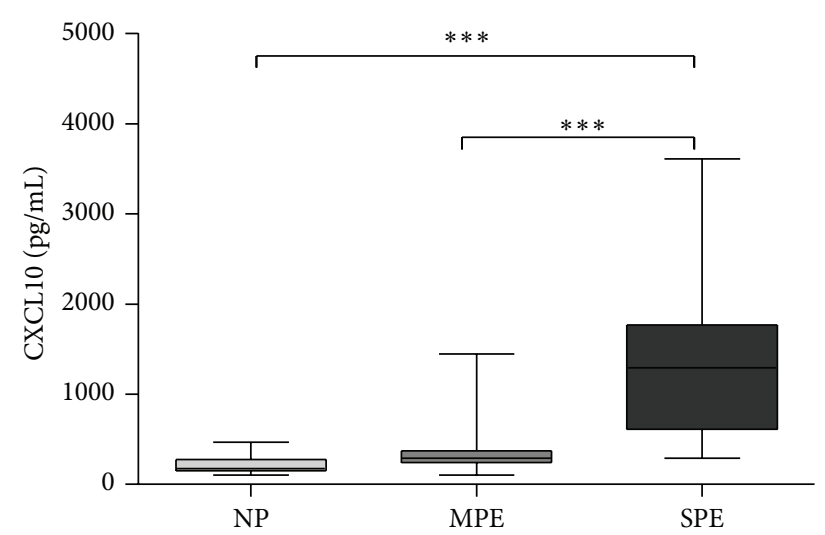

(a)

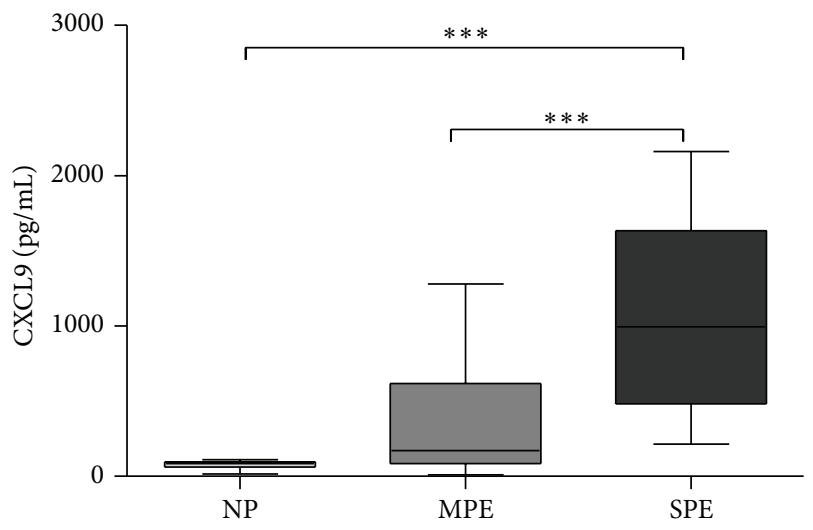

(c)

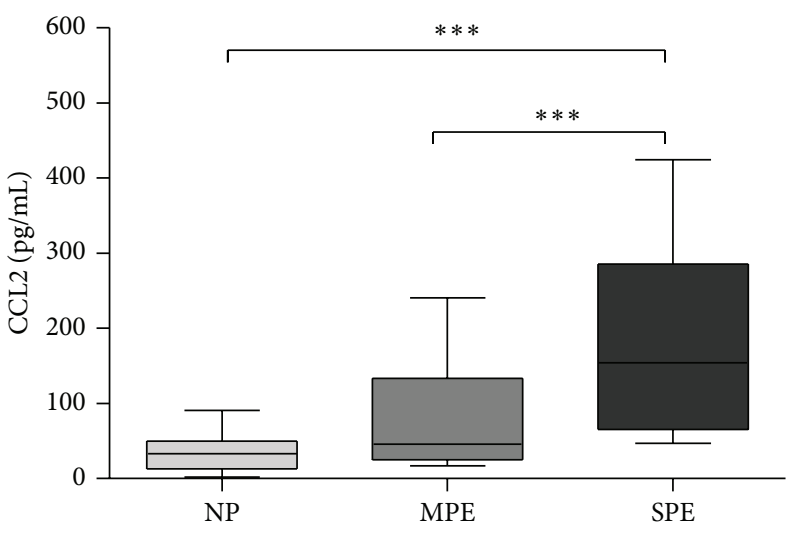

(b)

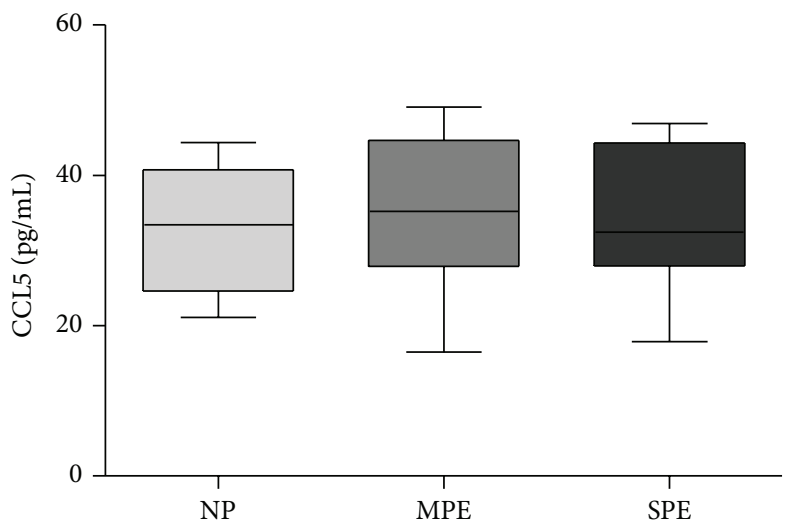

(d)

Figure 3: Chemokines related to antiangiogenic properties and inflammatory states are increased in preeclamptic patients. Plasma levels of inflammatory mediators are elevated in preeclamptic women. Plasma was obtained from normotensive pregnant $(n=51)$, moderated preeclamptic pregnant $(n=49)$, and severe preeclamptic pregnant $(n=24)$ women and inflammatory markers were analyzed by CBA microarray $\left({ }^{*} P<0.05,{ }^{* *} P<0.01,{ }^{* * *} P<0.001\right)$.

it is also well known that this cytokine is cytotoxic to villous trophoblast cultures. Additionally, a TNF- $\alpha$ soluble receptor attenuates preeclamptic-like features in pregnant rats $[9,36]$.

The circulating protein levels of other proinflammatory cytokines, such as IL-8, were also significantly elevated in SPE patients. This finding contradicts some works, which have demonstrated that, in placental tissue from patients with PE, IL- 8 is produced at lower concentrations, whereas in normal pregnancies, IL-8 production is related to angiogenic activity [37]. However, our data showed that a few SPE patients presented elevated IL-8 protein concentrations, as observed by other groups in maternal and fetus sera from PE patients [38].

Regarding IL-10, no differences between the levels of this cytokine were observed among the patient groups. IL-10 is mainly responsible for the suppression of inflammation. As reported in previous studies, we observed reduced numbers of $\mathrm{T}_{\text {regs }}$ in SPE patients, but with different systemic concentrations of IL-10. A few papers reported lower IL-10 expression in PE patients compared with healthy pregnant women. IL10 is also produced by Th2 cells, which is reduced during an immune response in PE [37, 38].
In this paper, we also evaluated the circulating levels of chemokines from PE, finding that CXCL9 and CXCL10 were elevated in SPE patients. It is well known that these chemokines possess antiangiogenic properties, but they are also linked with a Th1-type response because their genes are induced by IFN- $\gamma$ [39]. Additionally, the most important chemoattractant expressed by macrophages CCL2 was elevated in SPE patients. A number of hypotheses have been postulated to explain the onset of placental dysfunction during PE, including generalized endothelial dysfunction, inadequate trophoblast invasion at the fetoplacental junction, and inappropriate maternal inflammatory responses in the placenta $[1,40]$. Whether inappropriate inflammatory responses are a primary or secondary cause of preeclampsia remains to be determined.

\section{Conclusion}

Our findings show that the $\mathrm{T}_{\text {regs }}$ levels are reduced in patients with $\mathrm{PE}$ and that the systemic inflammatory status is linked with a severe PE state. 
Increased concentrations of IL- 6 , TNF- $\alpha$, and IL- 8 were found in Mexican women at different preeclamptic stages relative to NP patients; no differences in the IL- $1 \beta$ and IL-10 levels were detected. An analysis of chemokines in serum also showed higher concentrations of CCL2, CXCL9, and CXCL10 in preeclamptic samples.

\author{
Abbreviations \\ PE: Preeclampsia \\ $\mathrm{T}_{\text {regs }}$ : Regulatory $\mathrm{T}$ cells \\ NP: Normotensive pregnant \\ HC: Healthy controls \\ MPE: Moderated preeclamptic patients \\ SPE: Severe preeclamptic patients.
}

\section{Conflict of Interests}

The authors have declared that no competing interests exist.

\section{Authors' Contribution}

Mario Adan Moreno-Eutimio and José María TovarRodríguez contributed equally to this work. Mario Adan Moreno-Eutimio and José María Tovar-Rodríguez participated in the conception and design of the study, supervision of data collection, data analysis, and interpretation of the findings of the study, paper writing and revision. Nayeli Goreti Nieto-Velázquez and María Guadalupe Frías-De-León performed data analysis and participated in paper revision. Karina Vargas-Avila participated in the data collection. Mónica Sierra-Martinez and Gustavo Acosta-Altamirano helped with paper writing and revision.

\section{Acknowledgments}

The authors wish to acknowledge technical assistance from Q. Marina Perez-Ortiz and Q. Teresa Sandoval-Hernández. They would like to thank the staff at the Clinical Laboratory for their assistance throughout this study. This work was supported by Hospital Juárez de México and by The National Council of Science and Technology (CONACyT) through Grant SALUD-2012-01-182209 (awarded to Mario Adan Moreno-Eutimio).

\section{References}

[1] M. Noris, N. Perico, and G. Remuzzi, "Mechanisms of disease: pre-eclampsia," Nature clinical practice. Nephrology, vol. 1, no. 2, pp. 98-114, 2005.

[2] E. N. Sánchez-Rodríguez, S. Nava-Salazar, C. Morán, J. F. Romero-Arauz, and M. A. Cerbón-Cervantes, "The two leading hypothesis regarding the molecular mechanisms and etiology of preeclampsia, and the Mexican experience in the world context," Revista de Investigacion Clinica, vol. 62, no. 3, pp. 252260, 2010.

[3] O. Basso, S. Rasmussen, C. R. Weinberg, A. J. Wilcox, L. M. Irgens, and R. Skjaerven, "Trends in fetal and infant survival following preeclampsia," Journal of the American Medical Association, vol. 296, no. 11, pp. 1357-1362, 2006.

[4] A. Molvarec, Á. Vér, A. Fekete et al., "Association between estrogen receptor $\alpha$ (ESR1) gene polymorphisms and severe preeclampsia," Hypertension Research, vol. 30, no. 3, pp. 205211, 2007.

[5] A. Molvarec, Á. Jermendy, B. Nagy et al., "Association between tumor necrosis factor (TNF)- $\alpha$ G-308A gene polymorphism and preeclampsia complicated by severe fetal growth restriction," Clinica Chimica Acta, vol. 392, no. 1-2, pp. 52-57, 2008.

[6] K. Rosta, A. Molvarec, A. Enzsoly et al., "Association of extracellular superoxide dismutase (SOD3) Ala40Thr gene polymorphism with pre-eclampsia complicated by severe fetal growth restriction," European Journal of Obstetrics Gynecology and Reproductive Biology, vol. 142, no. 2, pp. 134-138, 2009.

[7] N. C. Serrano, "Immunology and genetic of preeclampsia," Clinical and Developmental Immunology, vol. 13, no. 2-4, pp. 197-201, 2006.

[8] A. Erlebacher, "Immunology of the maternal-fetal interface," Annual Review of Immunology, vol. 31, pp. 387-411, 2013.

[9] D. G. Harrison, T. J. Guzik, H. E. Lob et al., "Inflammation, immunity, and hypertension," Hypertension, vol. 57, no. 2, pp. 132-140, 2011.

[10] N. Ohkura, Y. Kitagawa, and S. Sakaguchi, “ Development and maintenance of regulatory T cells," Immunity, vol. 38, no. 3, pp. 414-423, 2013.

[11] J. D. Fontenot, M. A. Gavin, and A. Y. Rudensky, "Foxp3 programs the development and function of $\mathrm{CD} 4^{+} \mathrm{CD} 25^{+}$regulatory T cells," Nature Immunology, vol. 4, no. 4, pp. 330-336, 2003.

[12] V. R. Aluvihare, M. Kallikourdis, and A. G. Betz, "Regulatory T cells mediate maternal tolerance to the fetus," Nature Immunology, vol. 5, no. 3, pp. 266-271, 2004.

[13] S. Verlohren, D. N. Muller, F. C. Luft, and R. Dechend, "Immunology in hypertension, preeclampsia, and target-organ damage," Hypertension, vol. 54, no. 3, pp. 439-443, 2009.

[14] A. Zlotnik and O. Yoshie, "The Chemokine Superfamily Revisited," Immunity, vol. 36, no. 5, pp. 705-712, 2012.

[15] F. Azizieh, R. Raghupathy, and M. Makhseed, "Maternal cytokine production patterns in women with pre-eclampsia," American Journal of Reproductive Immunology, vol. 54, no. 1, pp. 30-37, 2005.

[16] A. Szarka, J. Rigo Jr., L. Lazar, G. Beko, and A. Molvarec, "Circulating cytokines, chemokines and adhesion molecules in normal pregnancy and preeclampsia determined by multiplex suspension array," BMC Immunology, vol. 11, article 59, 2010.

[17] A. Molvarec, A. Szarka, S. Walentin et al., "Serum leptin levels in relation to circulating cytokines, chemokines, adhesion molecules and angiogenic factors in normal pregnancy and preeclampsia," Reproductive Biology and Endocrinology, vol. 9, article 124, 2011.

[18] S. Saito, Y. Sasaki, and M. Sakai, "CD4+CD25high regulatory T cells in human pregnancy," Journal of Reproductive Immunology, vol. 65, no. 2, pp. 111-120, 2005.

[19] A. Steinborn, G. M. Haensch, K. Mahnke et al., "Distinct subsets of regulatory $\mathrm{T}$ cells during pregnancy: Is the imbalance of these subsets involved in the pathogenesis of preeclampsia?" Clinical Immunology, vol. 129, no. 3, pp. 401-412, 2008.

[20] J. R. Prins, H. M. Boelens, J. Heimweg et al., "Preeclampsia is associated with lower percentages of regulatory $\mathrm{T}$ cells in maternal blood," Hypertension in Pregnancy, vol. 28, no. 3, pp. 300-311, 2009. 
[21] Y. Sasaki, D. Darmochwal-Kolarz, D. Suzuki et al., "Proportion of peripheral blood and decidual $\mathrm{CD} 4^{+} \mathrm{CD} 25^{\text {bright }}$ regulatory $\mathrm{T}$ cells in pre-eclampsia," Clinical and Experimental Immunology, vol. 149, no. 1, pp. 139-145, 2007.

[22] D. Darmochwal-Kolarz, S. Saito, J. Rolinski et al., "Activated T lymphocytes in pre-eclampsia," The American Journal of Reproductive Immunology, vol. 58, no. 1, pp. 39-45, 2007.

[23] G. Toldi, J. Rigo Jr., B. Stenczer, B. Vasarhelyi, and A. Molvarec, "Increased prevalence of IL-17-producing peripheral blood lymphocytes in pre-eclampsia," The American Journal of Reproductive Immunology, vol. 66, no. 3, pp. 223-229, 2011.

[24] G. Toldi, S. Saito, T. Shima et al., "The frequency of peripheral blood CD4+ CD25high FoxP3+ and CD4+ CD25- FoxP3+ regulatory $\mathrm{T}$ cells in normal pregnancy and pre-eclampsia," The American Journal of Reproductive Immunology, vol. 68, no. 2, pp. 175-180, 2012.

[25] D. Hu, Y. Chen, W. Zhang, H. Wang, Z. Wang, and M. Dong, "Alteration of peripheral $\mathrm{CD} 4+\mathrm{CD} 25+$ regulatory $\mathrm{T}$ lymphocytes in pregnancy and pre-eclampsia," Acta Obstetricia et Gynecologica Scandinavica, vol. 87, no. 2, pp. 190-194, 2008.

[26] S. Paeschke, F. Chen, N. Horn et al., "Pre-eclampsia is not associated with changes in the levels of regulatory $\mathrm{T}$ cells in peripheral blood," The American Journal of Reproductive Immunology, vol. 54, no. 6, pp. 384-389, 2005.

[27] M. Knuist, G. J. Bonsel, H. A. Zondervan, and P. E. Treffers, "Risk factors for preeclampsia in nulliparous women in distinct ethnic groups: a prospective cohort study," Obstetrics and Gynecology, vol. 92, no. 2, pp. 174-178, 1998.

[28] J. Gong, D. A. Savitz, C. R. Stein, and S. M. Engel, "Maternal ethnicity and pre-eclampsia in New York City, 1995-2003," Paediatric and Perinatal Epidemiology, vol. 26, no. 1, pp. 45-52, 2012.

[29] M. A. Brown, M. D. Lindheimer, M. de Swiet, A. van Assche, and J. M. Moutquin, "The classification and diagnosis of the hypertensive disorders of pregnancy: statement from the International Society for the Study of Hypertension in Pregnancy (ISSHP)," Hypertension in Pregnancy, vol. 20, no. 1, pp. 9-14, 2001.

[30] A. Molvarec, A. Szarka, S. Walentin, E. Szucs, B. Nagy, and J. Rigó, "Circulating angiogenic factors determined by electrochemiluminescence immunoassay in relation to the clinical features and laboratory parameters in women with pre-eclampsia," Hypertension Research, vol. 33, no. 9, pp. 892-898, 2010.

[31] D. A. Somerset, Y. Zheng, M. D. Kilby, D. M. Sansom, and M. T. Drayson, "Normal human pregnancy is associated with an elevation in the immune suppressive CD25 + CD $4+$ regulatory T-cell subset," Immunology, vol. 112, no. 1, pp. 38-43, 2004.

[32] A. Erlebacher, "Mechanisms of $\mathrm{T}$ cell tolerance towards the allogeneic fetus," Nature Reviews Immunology, vol. 13, no. 1, pp. 23-33, 2013.

[33] U. G. Svendsen, "Evidence for an initial, thymus independent and a chronic, thymus dependent phase of DOCA and salt hypertension in mice," Acta Pathologica et Microbiologica Scandinavica-Section A Pathology, vol. 84, no. 6, pp. 523-528, 1976.

[34] B. LaMarca, J. Speed, L. F. Ray et al., "Hypertension in response to IL-6 during pregnancy: role of AT1-receptor activation," International Journal of Interferon, Cytokine and Mediator Research, vol. 3, no. 1, pp. 65-70, 2011.

[35] E. S. Purcell and V. H. Gattone II, "Immune system of the spontaneously hypertensive rat I. Sympathetic innervation," Experimental Neurology, vol. 117, no. 1, pp. 44-50, 1992.
[36] C. J. Lockwood, C.-F. Yen, M. Basar et al., "Preeclampsia-related inflammatory cytokines regulate interleukin-6 expression in human decidual cells," American Journal of Pathology, vol. 172, no. 6, pp. 1571-1579, 2008.

[37] Y. Wang, J. Baier, C. D. Adair et al., "Interleukin-8 stimulates placental prostacyclin production in preeclampsia," The American Journal of Reproductive Immunology, vol. 42, no. 6, pp. 375380, 1999.

[38] M. Tosun, H. Celik, B. Avci, E. Yavuz, T. Alper, and E. Malatyalioğlu, "Maternal and umbilical serum levels of interleukin-6, interleukin-8, and tumor necrosis factor- $\alpha$ in normal pregnancies and in pregnancies complicated by preeclampsia," Journal of Maternal-Fetal and Neonatal Medicine, vol. 23, no. 8, pp. 880886, 2010.

[39] F. Gotsch, R. Romero, L. Friel et al., "CXCL10/IP-10: a missing link between inflammation and anti-angiogenesis in preeclampsia?" Journal of Maternal-Fetal and Neonatal Medicine, vol. 20, no. 11, pp. 777-792, 2007.

[40] S. Kalkunte, T. Nevers, W. E. Norris, and S. Sharma, "Vascular IL-10: a protective role in preeclampsia," Journal of Reproductive Immunology, vol. 88, no. 2, pp. 165-169, 2011. 


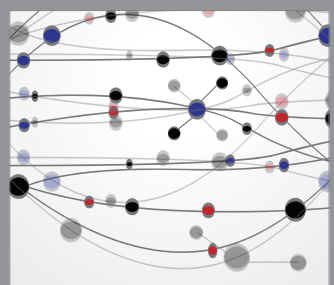

The Scientific World Journal
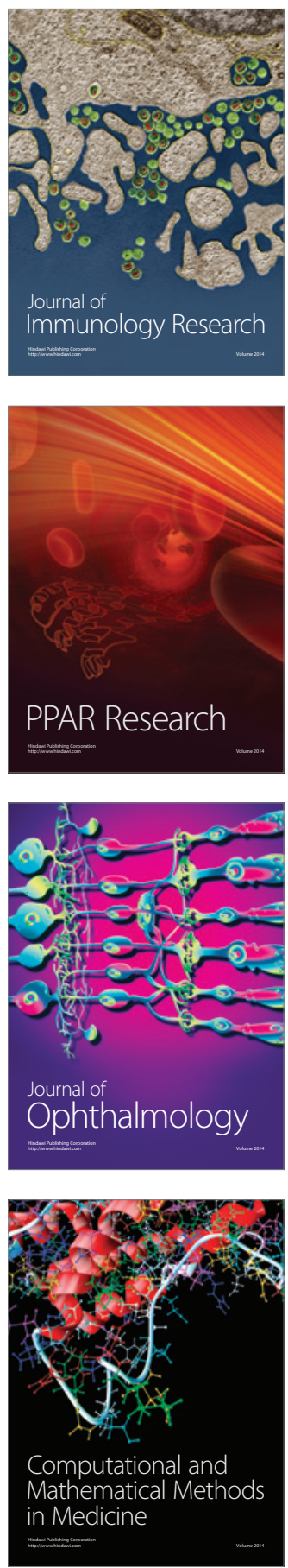

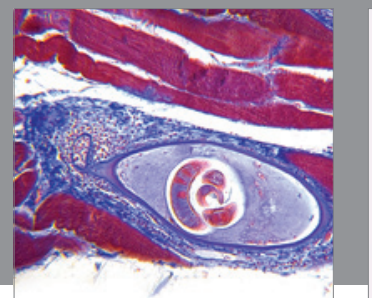

Gastroenterology

Research and Practice
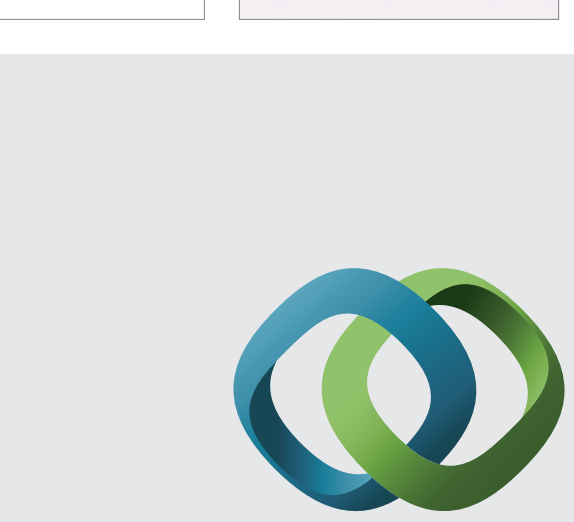

\section{Hindawi}

Submit your manuscripts at

http://www.hindawi.com
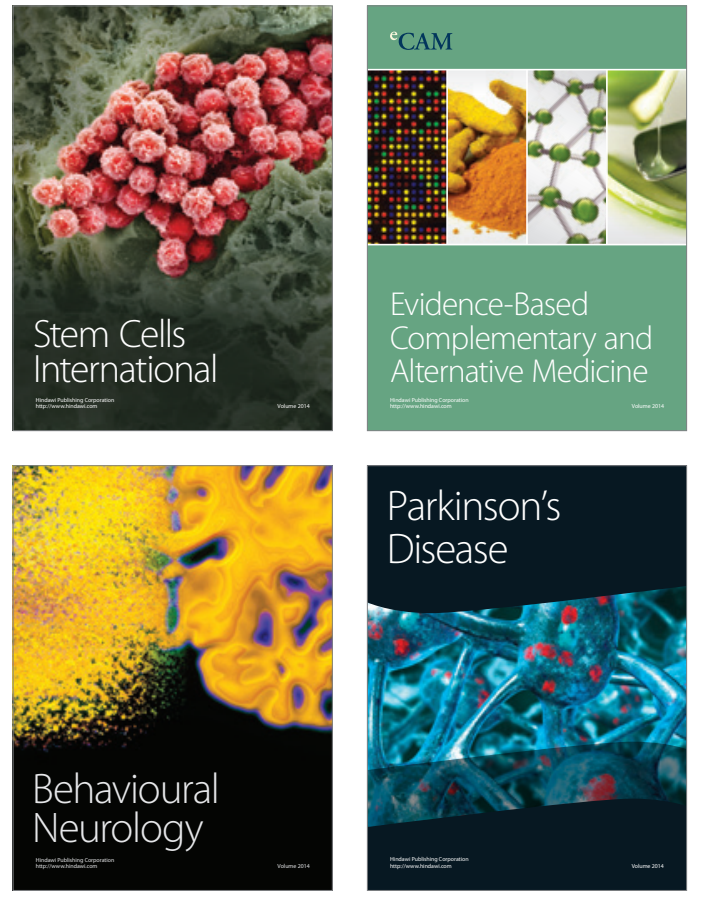
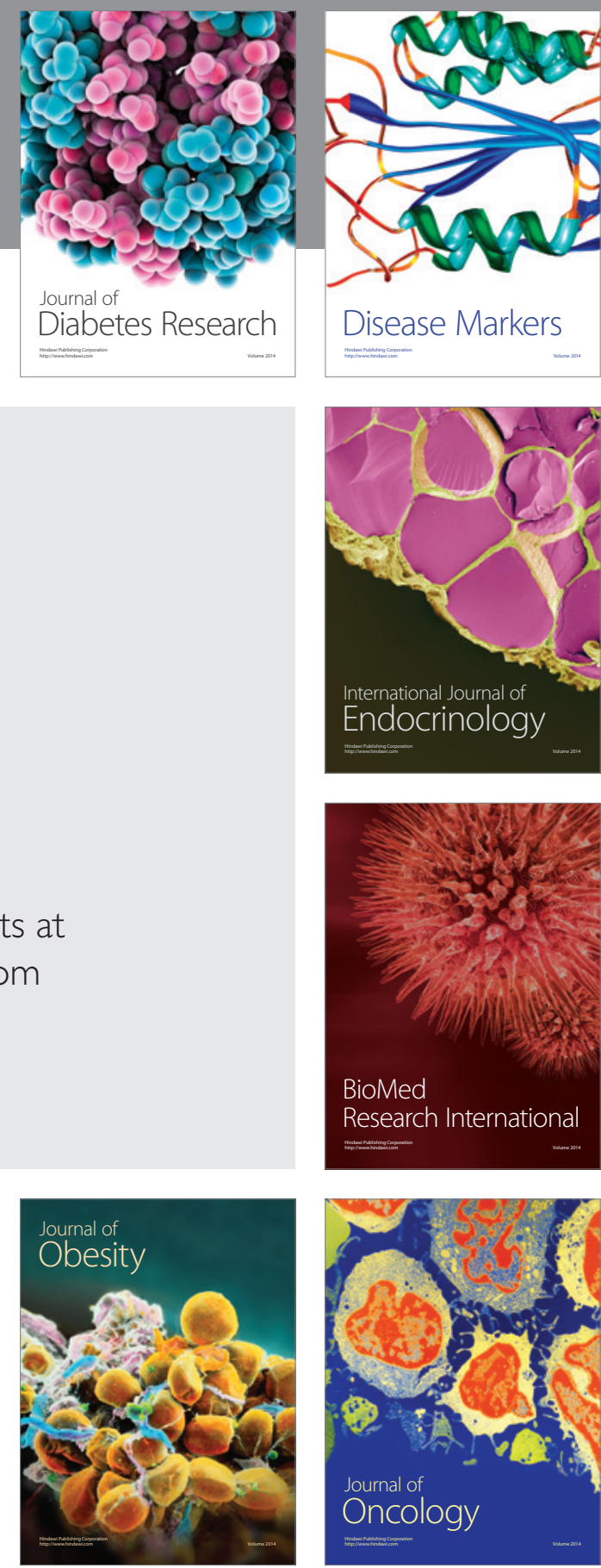

Disease Markers
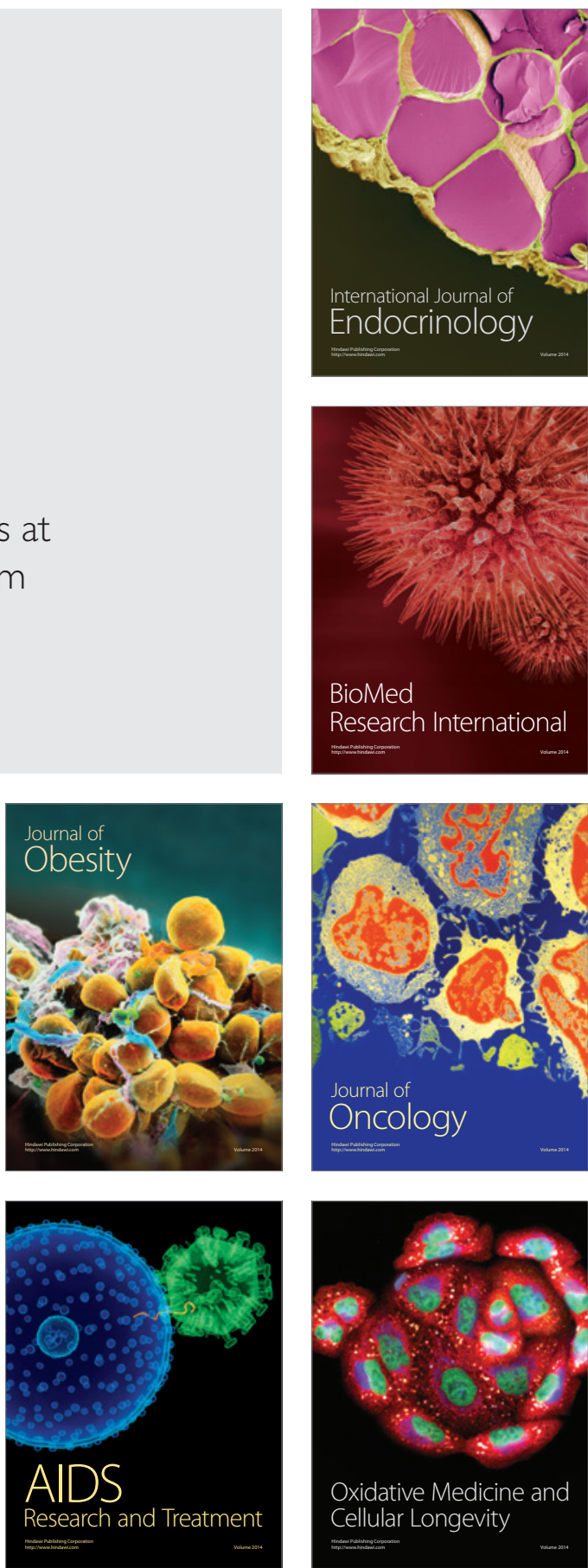